\title{
Introduction to Theme Issue: Electronic Networks and Democracy
}

NICHOLAS W. JANKOWSKI

The European Institute of Communication and Culture (Euricom) and the University of Nijmegen are engaged in a long-term investigation into understanding the problems and possibilities of electronic networks in democracies. The second in a series of colloquia on this topic was held October 2002 in Nijmegen, The Netherlands. Then, 60 scholars from across Europe, North America and Australasia convened and presented papers related to a single overriding question: In what manner and to what degree can electronic networks contribute to a more informed and politically active citizenry?

Many of the papers presented at this event are being revised for publication in four journal theme issues, scheduled for release during the course of 2003: Journal of Computer-Mediated Communication, Electronic Journal of Communication, Javnost-The Public, and Communications: The European Journal of Communication Research. This issue of Communications is one of the first collections to be completed and brings together contributions mainly from European participants at the event.

The issue leads off with a study by Peter Muhlberger from the Carnegie Mellon University in Pittsburgh, Pennsylvania, who tests the hypothesis that people who discuss politics on the Internet are essentially different from people who discuss politics offline. Based on a mail survey, one of the conclusions he draws suggests that Internet political discussion overrepresents younger people who are appreciably more conservative than their cohorts online.

Anna Malina, Director of Communities-Internet in Bishopton, Scotland and Associate of Models-Research in Ireland, considers the implications of forces shaping our use of technology and examines guidelines for various forms of e-government and e-democracy. She emphasizes need for empirical research, particularly in alliance with local groups. 
Heikki Heikkilä and Pauliina Lehtonen from the University of Tampere, Finland, take an interventionist stance towards digital democracy and cooperate with local groups in two Finnish towns in the implementation of special communication technology. Based on their studies, they conclude that traditional media may be more effective in some situations for communicating certain information than Web-based approaches.

Todd Graham and Tamara Witschge from the University of Amsterdam, The Netherlands, develop procedures for measuring deliberative democracy and test these procedures on a small-scale study of a UKbased discussion group.

Hilmar Westholm from the University of Bremen, Germany, examines government-driven forms of political participation supported with the aid of information technologies. He presents a case study of an online initiative designed to enhance consultation of government officials by citizens and makes recommendations for how governments should incorporate these technologies into their arsenal of materials for supporting citizen engagement.

As mentioned at the beginning of this introduction, other events are scheduled to follow the Euricom Colloquium held last October. First, a preconference is planned at the International Communication Association in May 2003 in San Diego. Also, plans for an international comparative research project, entitled Internet and Elections, are in an advanced state of development. This group hopes to hold a panel at the Association of Internet Researchers conference in Toronto in October 2003, and a special training workshop about Web archiving and analysis in Singapore in March 2004. At about the same time, a revised and edited selection of the papers originally prepared for the two Euricom Colloquia will be published in a book series available from Hampton Press - Euricom Monographs.

All of these activities are related to what has come to be known as the Euricom Project. One of the main objectives of this project is to undertake research concerned with the societal implications and impacts of electronic networks on democratic institutions and practices during the coming decade. Central to this objective is the need to develop an ongoing working group, including both young and established researchers, concerned with the enactment of this agenda through long-term exploration of electronic networks. The above-mentioned project, called Internet and Elections, is a step in that direction. More information on the Euricom Project can be found at: http://oase.uci.kun.nl/ jankow/Euricom. In closing, I wish to thank the institutions that made the 2002 Euricom Colloquium financially possible: the European Commission program for High-Level Scientific Conferences, the Ford Foundation, the U.S. National Science Foundation, the Netherlands Organization for Scientific 
Research, the Amsterdam School of Communication Research, and the University of Nijmegen, which hosted the event. I also wish to thank Michelle Camps and Marian van Bakel for their onsite logistic support during the Colloquium. Special words of appreciation are due to Marieke Jansen who was responsible for the organization of post-colloquium virtual meetings and for the editorial preparation of these articles. Finally, I would like to thank all of the participants in the Euricom Colloquium for their contributions to this long-term scholarly endeavor at investigating the relationship between electronic networks and democracy. 